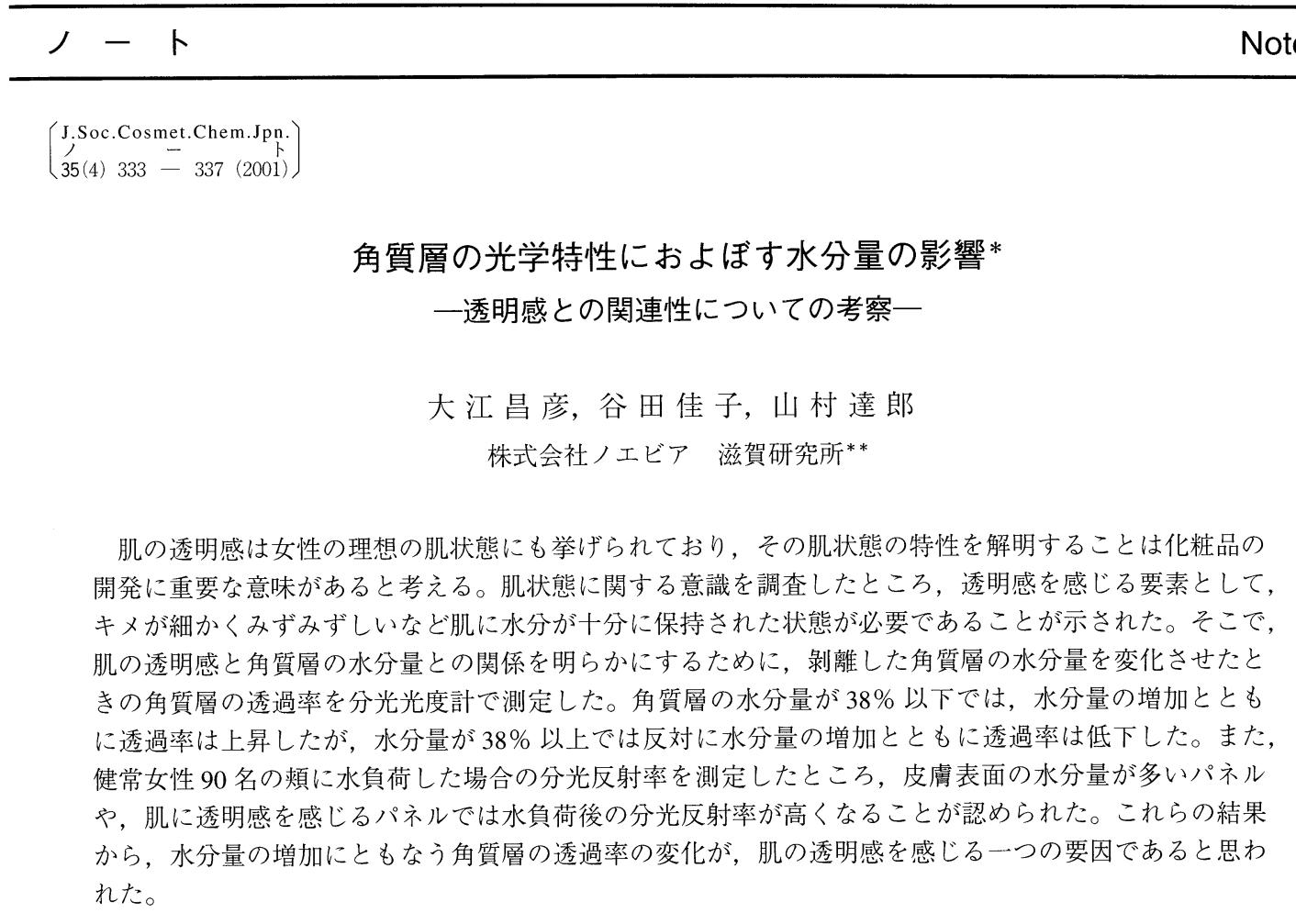

\section{1. 緒言}

皮膚は生体を維持するためのバリアであるとと もに，外観を決定する重要な因子である。特に角 質層の水分量は, 肌のつややかさやしなやかさな ど見た目の美しさに大きく影響する。すなわち， 十分にうるおいのある肌は透明感やつやがあり美 しいが, 乾燥により表面の状態が悪化すると外観 の美しさが失われる。これは，水分量の減少によ る肌理など肌表面の微細な形状变化や，角質層の 透明度が低下することなどに起因するものと考え られている1)-3)。肌状態に関するイメージを調査 した結果, 透明感を感じる要素としては肌理が細 かくみずみずしいなどの, 水分が保持された肌が もつ特徵が示されている。また, 透明感を感じや すいのは，洗顔や入浴後などの肌に水分が過剩に あるときとの回答が多かった。このことから，水

*2001.5.10 受理

** ₹527-8588 八日市市岡田町 112-1: 112-1, Okadacho, Yokaichi 527-8588, Japan
分量の変化にともなう角質層透明度の変化が肌の 透明感を感じる一つの要因であると予想される。

そこで今回われわれは，肌表面の水分量を変化 させたときの角質層内部への光の透過および肌表 面での反射特性を測定し，水分量と肌状態や外観 の変化との関係を調べた。

\section{2. 実験}

\section{1. 透明感に関する意識調査}

20６0 代の一般女性 90 名を対象に，透明感の ある肌の状態についてのイメージをグループイン タビューによって調査した。また，日常生活や生 活環境等で透明感を感じる状況を, 記述式のアン ケートで調査した。

\section{2. 角質層透明度と反射率の測定}

日焼けにより剝離したヒト背部の角質層を減圧 下シリカゲルデシケーター中で乾燥させた後, 400〜700 nm での透過率を分光光度計（日立製作 所社製，U-3000）で測定した。また，含有水分 量と透過率との関係を調査するために，蒸留水を 
負荷して角質層水分量を変化させたときの透過率 を測定した。なお，角質層に含まれる水分量は， 一定時間蒸留水に浸した後の重量変化から求めた。 さらにユカタンブタの皮膚を 1 昼夜冷蔵庫でディ スパーゼ溶液（10,000 unit/10 mL PBS，合同酒精 社製）で処理し，剝離した表皮をトリプシン処理 (15,000 unit/10 mL PBS, GIFCO 社製) すること で単離した角質層を用いて，水分量と透過率の関 係について同様の検討を行った。

また，含有水分量と反射率の関係を調查するた めに, 蒸留水を負荷して角質層水分量を変化させ たときの反射率を分光測色機 (ミノル夕社製, CM2002）を用いて, 表面反射のない黒いシリコン樹 脂（反射率 2〜3\%）上で測定した。

\section{3. 頪の反射率の測定}

煩の反射率と光学特性の関係を明らかにするた めに, 煩の分光反射率を分光測色機を用いて測定 した。正反射光成分を除くSCEモードで測定し，

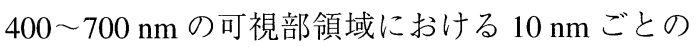
反射率 31 ポイントを合計したものを, 肌表面で の拡散反射率光量の指標とした。なお, 頬の同一 部位を 3 回測定して平均值を求めた。

\section{4. 肌状態と反射率}

20〜60 代の健常な女性 90 名を対象に㚘頁の反射 率を測定した後，蒸留水を含ませたコットンを 3 分間のせて水分を浸透させ，同一部位で再度反射 率を測定した。また, 反対側の賸で Skicon（IBS 社製）を用いて水分量を測定した。さらに，2 名 の専門評価者により目視で煩の透明感を観察し, 当社客観評価基準を用いて 5 段階でスコア化した (スコア；1：ない, 2：あまりない, 3：普通, 4： ややある，5：ある)。

\section{3. 結果ならびに考察}

\section{1. 透明感に関する意識調査}

透明感を感じる肌の状態を表す言葉についてグ ループインタビューで調査した結果を Table-1に 示した。透明感を感じる要因としては,「キメが 整っている」や「色ムラがない」等が挙げられ， これらを分類すると肌色や色素に関する項目と肌 の水分量に関係する項目に分類できた。また，自
己認識において透明感を感じやすい状況を調べた ところ,「風呂上がり」「洗顔直後」また「化粧水 使用直後」と，いずれも肌にうるおいが十分にあ るときに感じるとの回答が多く, 肌の水分量が透 明感を感じる要因として重要であることが推察さ れた $($ Table-2)。

\section{2. 剝離角質層の透明度}

背部より豩離した角質層を用いた水分負荷によ る透過率の変化を Fig. -1 に示した。角質層を蒸

Table-1 Consideration recognition survey result concerning transparency $(n=90)$.

\begin{tabular}{ll}
\hline What is the skin with a transparency? & \\
\hline - Texture of fine & $52.3(\%)$ \\
- Skin color is white & 38.6 \\
- There is no irregular color & 34.1 \\
- It is grossy to the skin & 22.7 \\
- It is fresh & 13.6 \\
\hline
\end{tabular}

Table-2 The results of recognition survey about transparency $(n=40)$.

When do you feel a transparency of the skin?

- Going up in bath

- After washing one's face

- After applying the skin lotion

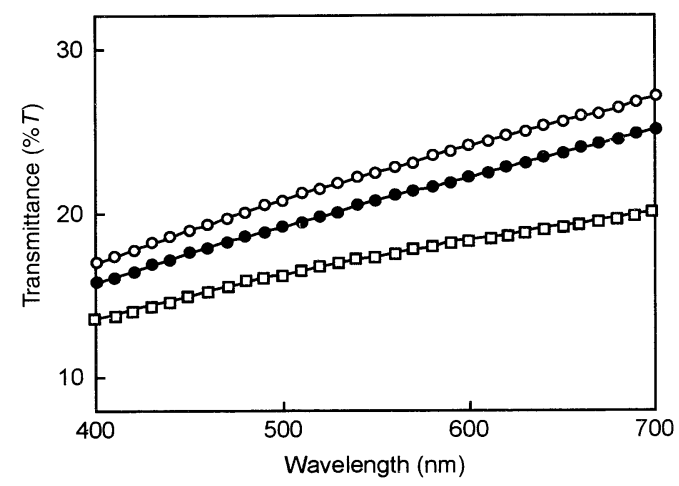

Fig. - 1 The transmittance of an exforiation stratum corneum with and without hydration.

$\longrightarrow$ : dry stratum corneum, $\longrightarrow-$ - : after water loading with $5 \mathrm{~s}, \longrightarrow$ - : after water loading with $5 \mathrm{~min}$. 
留水に浸して水を負荷したところ, 短時間の処理 で透過率は一時的に上昇するが，長時間（5分間） 水に浸して過度の水を負荷した場合には, 逆に透 過率の減少が確認された。このことから, 角質層 の透明度は水分量によって大きく変化すると考え られる。そこで, 角質層の水分量を変化させたと きの透過率変化を Fig. -2 に示した。Fig. -1 に示 したプロフィールから波長特異的な変化が認めら れなかったため, 角質層水分量と透過率の関係は $700 \mathrm{~nm}$ の透過率で示した。Fig. -2 より, 含水分

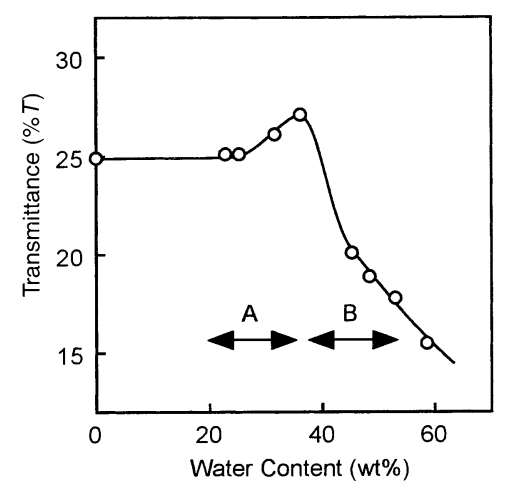

Fig.-2 Relationship between transmittance at $700 \mathrm{~nm}$ and water content of stratum corneum.

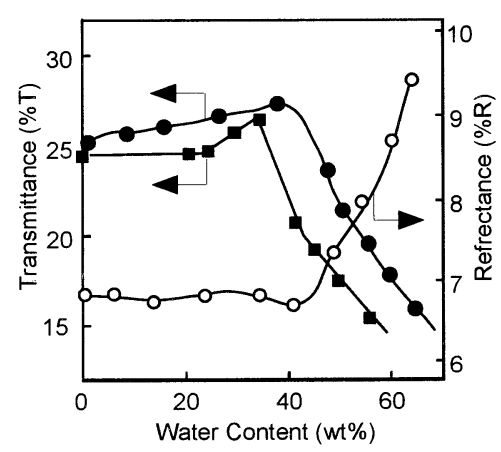

Fig. - 3 The relationship between transmittance or reflectance and water content of stratum corneum.

- : the transmittance of human stratum corneum, - : the transmittance of pig stratum corneum, $-\mathrm{O}-$ : the refrectance of pig stratum corneum.
量が $20 \%$ までのとき透過率は $25 \%$ 程度で一定の 值を示すが，20\%から $37 \%$ までの間では水分量 の増加とともに透過率は上昇した。さらに $37 \%$ 以上の水分が存在すると透過率が低下寸ることが 認められた。これは過剩水分の存在によるケラチ ンタンパクの膨潤に由来する可能性が考えられる が，角質層に水分が過剩に存在した場合には角質 層内部での光の散乱が高まり, 透過率が低下する ことで肌が白く見えることが予想された。また， ユカタンブタ皮膚から単離した角質層に水分を負 荷したときの透過率変化についても同様の傾向が 確認された (Fig. - -3)。このことから, 日焼けに より剝離した角質層についても，水分量変化にと もなう光学特性の変化は正常な角質層と同じであ ると考えられた。

\section{3. 肌状態と反射率}

in vivo において非侵襲的に角質層の透過率を 計測することは困難である。角質層の透過率に関 するパラメータとして皮膚表面での反射率が考え られるが, 反射強度は角質層内部での透過・散 乱・吸收の影響を受けることが予想される。そこ で, ユカタンブタ皮膚から剝離した角質層を用い て，水分を負荷したときの反射率变化を測定した。 その結果，角質層に過剩な水分を負荷し透過率が 低下する場合には表面での反射率が増加しており， 水分量変化に対する角質層の透過率と反射率が逆 相関することが確認できた。これは，水分量が増 加した場合には角質層内部での光の散乱が高まる ために透明度が減少して, 反射率が増加したこと を示している。また, 透過率と反射率が逆相関す ることから, 角質層内部での光の吸収の影響はほ とんどないと考えられた。そこで，透過率に関連 するパラメータとして反射率を測定して水分量と の関連を調査した。20代から60代の女性 90 名 の煩に水負荷を行い, その水負荷前後での反射率 を計測した。その結果, 水負荷前後で反射率が上 昇するパネルと反対に反射率が低下するパネルが 見られた (Fig. -4)。このとき, 水負荷前後で分 光反射率の変化に波長特異性が見られないことか ら, 可視領域 $(400 \sim 700 \mathrm{~nm})$ における $10 \mathrm{~nm}$ との反射率の和を肌表面での反射光量の指標とし 

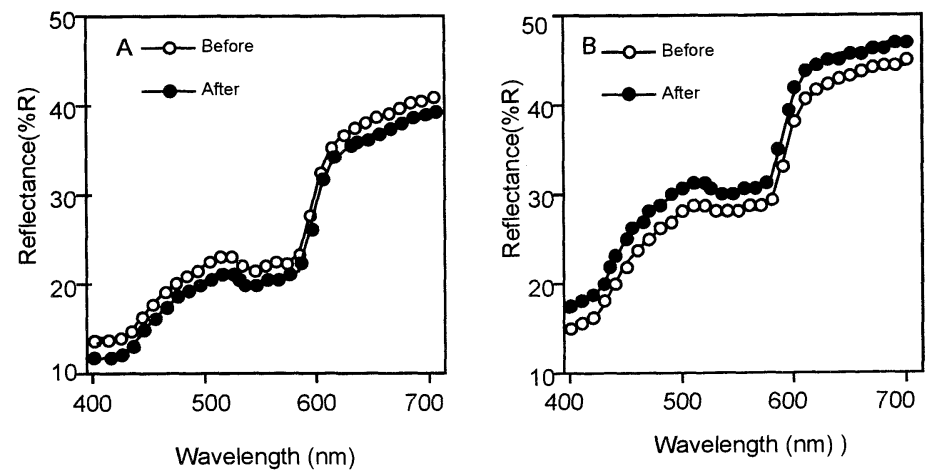

Fig. - 4 The examples of reflectance change before and after water loading. The reflectance decreased by water loading (A), and increased by same treatment in the other panel (B).

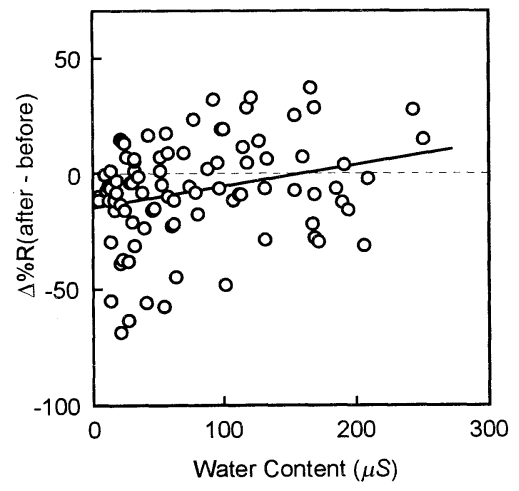

Fig. -5 The plots of the amount of surface moisture of a cheek vs. the difference of reflectance after and before water loading $(r=0.266, p<$ $0.05)$.

て用いた。

また，肌表面の水分量と水負荷前後での反射率 との関係を調べたところ, 表面水分量の増加とと もに水負荷後の反射率が増加することが認められ

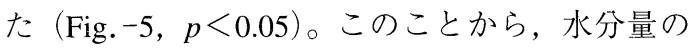
少ないパネルは水負荷によって透過率は増加し, 逆に水分量の多いパネルの角質層は水負荷によっ て透過率が減少したものと推察される。

次に目視の透明感と煩の水負荷前後の反射率の 関係を調べたところ，表面水分量の場合と同様に 透明感を感じるパネルでは反射率の差が正の值を 示した。つまり, 水負荷によって角質層の透過率

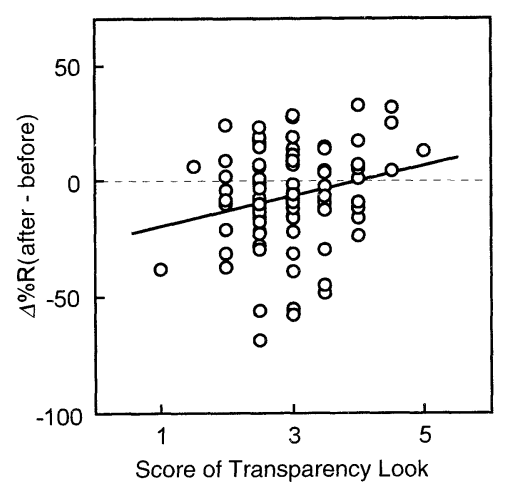

Fig. -6 The plots of score of transparency (feeling) look vs. the difference of refrectance after and before water loading $(r=0.222, p<0.05)$.

が低下したものと考えられた (Fig. - 6)。角質層 の透過率のパラメータとしてin vivo の皮膚反射 率が対応していると仮定した場合，これまでの結 果を総合的に解析することにより，肌の透明感に ついて以下の仮説が提案される。

過㮃の水分量が角質層に存在したとき，角質層 内部での光の散乱が増加するため透過率は低下す る。これをもとに皮膚表面水分量と水負荷前後で の反射率の差を解析すると, 水分量の少ないパネ ルに㧍ける反射率の低下は Fig. -2 での透過率上 昇の領域 $\mathrm{A}$ に, 水分量の高いパネルの反射率の 上昇は透過率の低下寸る領域 B に角層水分量が 変化したものと考えられる。さらに，目視による 
透明感スコアにおいて透明感の高いパネルにおけ

る水負荷前後での反射率の上昇も, 水負荷により

角層水分量が領域 $\mathrm{B}$ に変化した結果と思われた。

しかし, 今回の検討において透明感を感じるポ

イントが角層水分量として領域 $\mathrm{A} に$ 存在してい

るのか, 領域 B に存在しているのかは不明であ

る。今後このポイントを明確にするために, 角質

層の光学特性と水分量の関係を詳細に調査検討の
予定である。

\section{引用文 献}

1）高橋元次，粧技誌，34，5-24 (2000)

2）金子 治, 川口由起子, 石川好江, 稲垣和正, 粧技誌, 31, 429-438 (1997)

3）政野光広，村松宣江，湯浅正治，粧技誌，16, 1518 (1982)

\title{
Influence of Hydration for Optical Properties of Stratum Corneum*
}

\author{
Masahiko Ooe, Keiko Tanida, Tatsuo Yamamura \\ Shiga Research Laboratories, NOEVIR Co. Ltd. ${ }^{* *}$
}

\begin{abstract}
Transparent skin is demanded as the ideal skin condition by the majority of women. Therefore to analyze its characters in scientific aspects is an important study for the development of cosmetics. The recognition survey for skin transparency withdrew that water holding into stratum corneum was a critical parameter. Therefore, to clarify whether the skin transparency referred by women is related to the transmittance of stratum corneum or the water contents, the relationship between the transmittance of stratum corneum and water contents were examined by using the peeled human stratum corneum in vivo. The adequate hydrations in the stratum corneum (until $38 \% \mathrm{H}_{2} \mathrm{O}$ per $\mathrm{SC}$ weight) exhibited gradually to increase the transmission, however, excess hydration conversely decreased. Furthermore, women who had a higher value of water contents or claimed higher transparency themselves showed to increase the reflection on skin surface under excess hydrated conditions. From these findings, it was speculated that the skin transparency claimed by women was caused by the transmittance of the stratum corneum. In this study, we proposed one possible factor for the skin transparency.
\end{abstract}

Key words : hydration, optical property, stratum corneum, recognition survey, transparency, skin condition, transmittance, water contents, spectrophotometer, reflectance 